\title{
Two Cases of Lafora Disease Diagnosed By Genetical Tests
}

\section{고 Aylin BICAN DEMIR, (1) Ibrahim HAKKI BORA}

Department of Neurology, Bursa Uludag University Faculty of Medicine, Bursa, Turkey

\begin{abstract}
Epilepsy develops related to a complex genetic heredity as many diseases in society. Lafora disease (LD) is an autosomal recessive inheritance. It is localized at EPM2A gen 6q23-25 and encodes tyrosine phosphatase (Laforin protein). About $80 \%$ of the patients have mutations in this gene. In a case of $L D$, rapid and progressive dementia and frequent occipital seizures are clinical symptoms. For definitive diagnosis, through genetical study, EPM2A and EPM2B genes should be analyzed. A male at the age of 18, with a medical history of meningitis and seizures with high temperature. Starting from the age of 10 , there have been symptoms such as generalized tonic-clonic (GTC) seizures, startles in the whole body, and forgetfulness. In genetical tests, homozygote deletion of adenine nucleotide in the position of 468 at codon 156 and guanine nucleotide in the position of 469 at codon 157 is found. In other words, there has been dinucleotide deletion which is compatible with LD. A 20-year-old male was examined because of such symptoms as forgetfulness, myoclonia, hallucinations, and GTC clonic seizures. He was diagnosed with LD because of the heterozygote transformation of CCC to CTC at codon 111. Even though genetic disorders have many different reasons, it is advised that every society should have their own advanced studies on gene mutation. In Turkish cases, both of these genes were found mutated, each in different patients through various studies.
\end{abstract}

Keywords: Epilepsy; genetics; Lafora disease.

Cite this article as: Bican Demir A, Hakki Bora I. Two Cases of Lafora Disease Diagnosed By Genetical Tests. Epilepsi 2021;27:249-252.

\section{Introduction}

Lafora disease (LD) was first described by Lafora and Gluech in 1911. It is a rare subtype of progressive myoclonic epilepsy showing autosomal recessive inheritance. It is characterized by tonic-clonic seizures, myoclonus, visual hallucinations, progressive neurological destruction, and Lafora bodies, which usually begin in adolescence. Lafora bodies are intracellular polyglucosan inclusion bodies stained with periodic acid-Schiff (PAS) on the brain, retina, heart, liver, muscle, and skin. ${ }^{[1]}$ Genetic studies have been associated with LD genes EMP2A encoding Laforin protein, a phosphatase, and NHLRC1 (formerly EMP2B) encoding the malignant protein ubiquitin ligase..$^{[2]}$

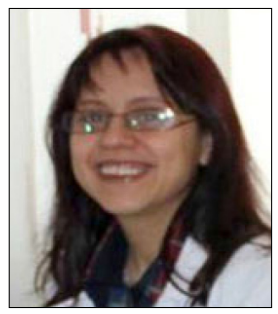

Corresponding author Aylin BICAN DEMIR, M.D. e-mail aylinbican@mynet.com

Received 14.02.2021

Accepted 06.04.2021

Online date 09.11.2021

Content of this journal is licensed under a Creative Commons Attribution-NonCommercial 4.0 International License.

C 2021 Turkish Epilepsy Society

\section{Case Report}

Case 1- A 17-year-old male patient was admitted to our outpatient clinic with a 5-month history of forgetfulness, increasing willingness to sleep, decreased communication skills, and frequent attacks of falls. It was learned that shortterm leaps started on his hands at the age of 12 years and generalized tonic-clonic (GTC) seizures developed a few months later. Valproic acid (VPA) treatment was initiated at the age of 14 by another hospital and carbamazepine treatment was added because his GTC seizures started again. During the follow-up, treatment with levetiracetam was continued, especially due to the exacerbation of myoclonic seizures. For the past 2 months, she had to drop out of school because her school performance declined due to leaps, falling, imbalance, misunderstanding, and speech disturbance, which became evident with audible external stimuli. It was stated that the patient had lost weight. His parents were consanguineous marriages and were cousins. In neurological examination; she was in a moderate condition in general, limited cooperation, marked ataxia, and dysarthric speech. She had spontaneous negative myoclonic seizures with an audible stimulus.

Case 2- A 16-year-old male patient presented with a GTC seizure, imbalance, and occasional startle. She had a history of meningitis at the age of 8 months. Levetiracetam 


\section{Genetik Testlerle Tanı Konulan İki Lafora Hastalığı Olgusu}

\section{Öz}

Epilepsi, toplumda sık görülen hastalıkların çoğu gibi kompleks bir genetik geçişe bağlı olarak gelişir. Lafora Hastalığı otozomal resesif kalıtım özelliği gösterir. EPM2A geni 6q23-25 bölgesine lokalizedir ve tirozin fosfataz (Laforin proteini) genini kodlar. Bu gendeki mutasyonlar hastaların \%80'inde bulunur. Lafora hastalığı saptanan bir olguda, hızlı ve progresif seyirli demans, sık oksipital nöbetler tanıda klinik ip uçlarıdır. Tanı; deri biyopsisinde Lafora cisimciği saptanması ile desteklenmektedir. Genetik araştırma ile EPM2A ve EPM2B genlerinin analizi kesin tanı koydurucudur. On sekiz yaş erkek hasta, sekiz aylıkken menejit ve ateşli havale öyküsü olup 10 yaşında başlayan jeneralize tonik klonik nöbetler ve zamanla tüm vucutta irkilme ve unutkanlık şeklinde şikayetleri de oluyormuş. Hatsanın genetik testlerinde kodon 156 bölgesinde 468 . pozisyonda bulunan Adenin nükleotidi ile kodon 157 bölgesinde 469. pozisyonda bulunan Guanin nükleotidinin homozigot delesyonunu saptadık. Yani hastada homozigot AG dinükleotid delesyonu mevcut olup Lafora ile uyumlu idi. Yirmi yaşında erkek hasta unutkanlığı, miyoklonileri ve görsel halüsinasyonları ve jeneralize tonik klonik nöbetleri nedeniyle tetkik edilen hastanın kodon 111 bölgesinde CCC'den CTC'ye heterozigot dönüşüm ile lafora olarak tanısı konuldu. Genetik farklıların bir çok sebebleri olmakla beraber toplumların kendi gen mutasyonlarının saptamasına yönelik ileri çalışmaların yapılması önerilmektedir.Türk olgularda bu genlerin ikisi de farklı bireylerde olmak üzere mutasyona uğramış olarak bulunduğu yapılan birçok çalışma ile gösterilmiştir.

Anahtar sözcükler: Epilepsi; genetik; Lafora hastalığı.

treatment was started at the center where he was admitted for the $1^{\text {st }}$ time when he had a 15-year-old GTC seizure and carbamazepine was added to his treatment due to the persistence of seizures under the current therapy. The patient developed imbalance and clumsiness. Educational success has decreased. VPA and levetiracetam were chosen as the main therapy during follow-up. In the neurological examination, his general condition was good, he was cooperative and oriented. There was no motor and sensory deficit but mild ataxia.

Laboratory examination of both cases; complete blood count, liver and kidney function tests, electrolytes, blood lactate, ammonia, Vitamin B12 level, and VPA blood level were normal. Blood and urine amino acids, urine organic acids, and fundus examination were normal too. In case 1, the neuropsychological tests revealed a low level of attention and perception and an IQ level of 50. Cranial magnetic

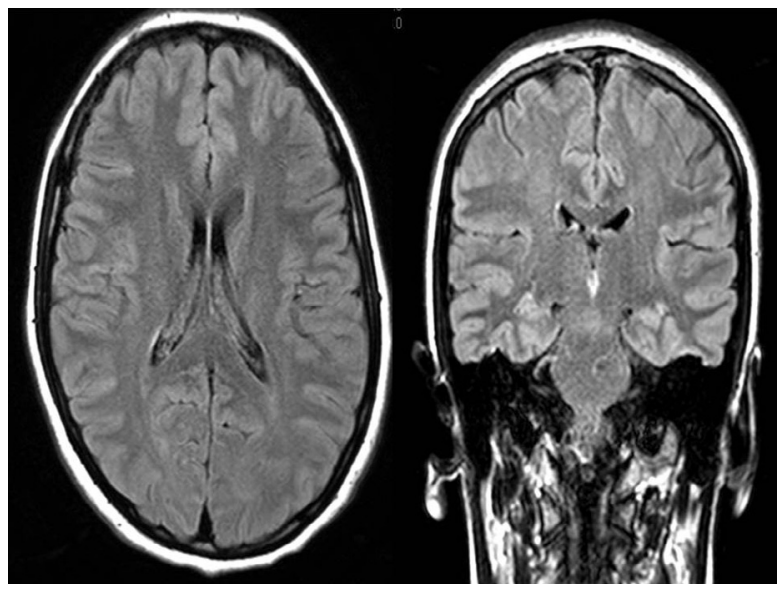

Fig. 1. Cranial magnetic resonance imaging was normal in both cases. resonance imaging was normal in both cases (Fig. 1). Electroencephalography (EEG) showed slowing of basic activity and continuous generalized spike and multiple spike waves (Fig. 2). Giant responses were obtained in the posterior tibial somatosensory evoked potential examination. In the armpit sweat gland biopsy, intracytoplasmic PAS (+) inclusions were observed in the eccrine and apocrine glands (Fig. 3).

In the genetic test of case 1 , heterozygous c.332C $>T$ (pP111L) mutation was detected in the NHLRC1 gene (Fig. 4). In the genetic test study of case 2, the EPM2A gene was normal and the homozygous c.468-469delAG (p.G158fsX16) mutation in the NHLRC1 gene was detected (Fig. 5). We observed that it was the most common mutation in this gene, similar to other studies. Myoclonic and GTC seizures at an early age, progressive mental destruction, ataxia, and dysarthria were diagnosed as progressive myoclonic epilepsies.

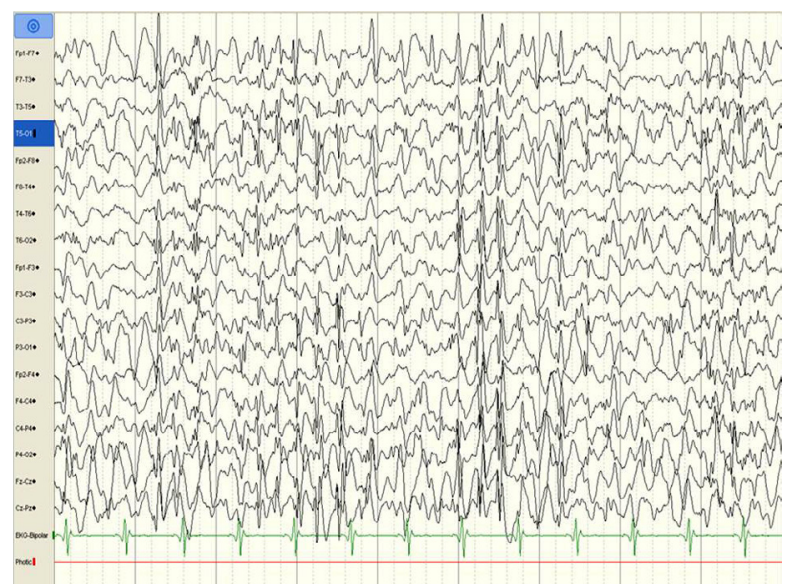

Fig. 2. Electroencephalography showed slowing of basic activity and continuous generalized spike and multiple spike waves. 


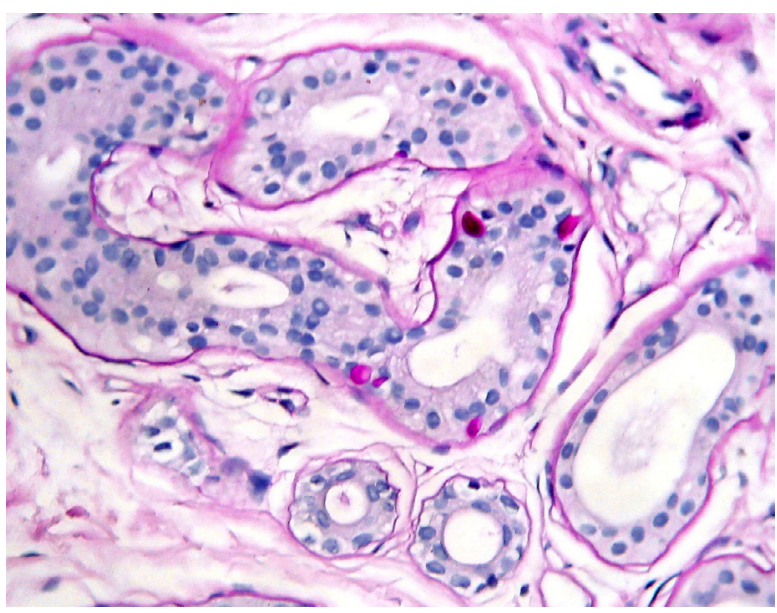

Fig. 3. In the armpit sweat gland biopsy, intracytoplasmic PAS (+) inclusions were observed in the eccrine and apocrine glands.

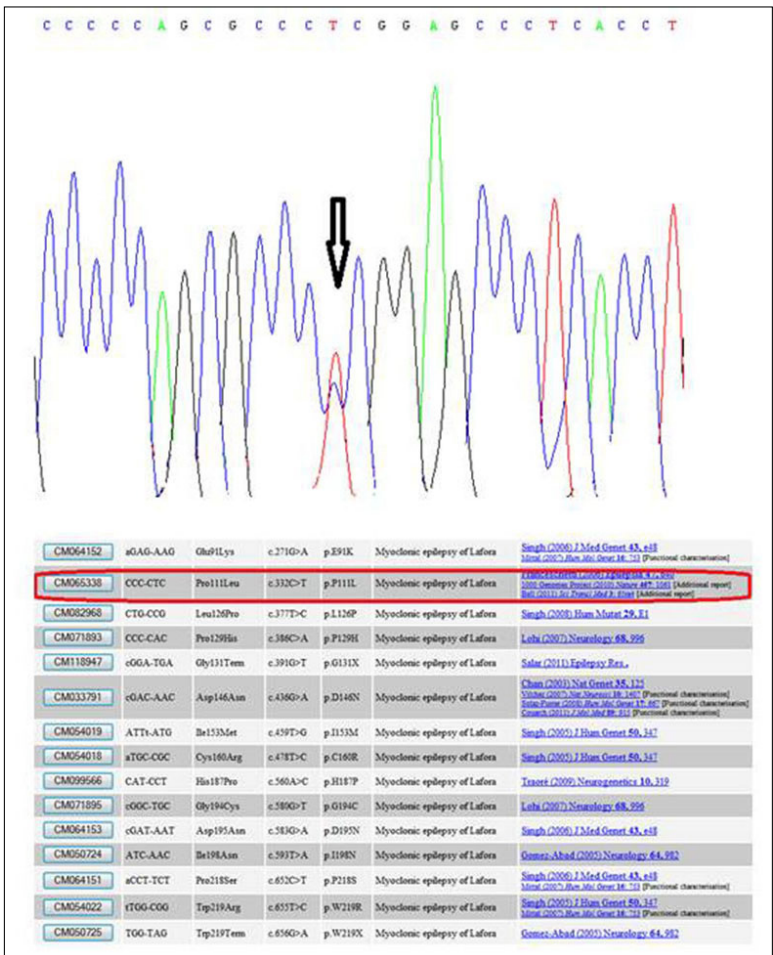

Fig. 4. In the genetic test of case 1, heterozygous c.332C >T (pP111L) mutation was detected in the NHLRC1 gene.

\section{Discussion}

LD is a progressive disease in the PME group, resulting in the decease of the patient in approximately 10 years. The age of onset is 12-15 years and patients usually show normal neurological development until the onset of the disease. In LD; myoclonus, transient blindness, and visual hallucinations, occipital seizures, atypical absence seizures, atonic,

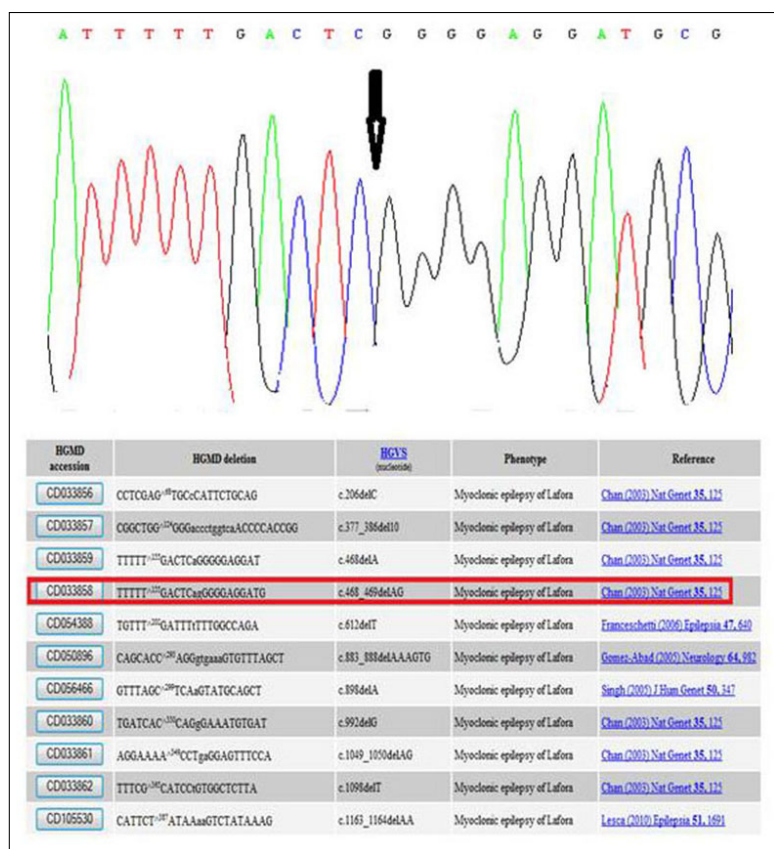

Fig. 5. In the genetic test study of case 2, the EPM2A gene was normal and the homozygous c.468-469delAG (p.G158fsX16) mutation in the NHLRC1 gene was detected.

and complex partial seizures can be seen. Characteristically, visual seizures are the first symptoms to appear. Myoclonus is very prominent, usually triggered by posture, action, or external stimuli (light, sound, and touch), may include facial and bulbar muscles outside the limb, maybe bilateral synchronous or multifocal or asynchronous. In addition, seizures become more resistant and status epilepticus can develop from any type of seizure. ${ }^{[3]}$

In general, high amplitude, spike-wave, and multi-spike wave discharges are observed in EEG starting from the onset of LD. In EEG studies, spike and wave patterns are observed at $3 \mathrm{~Hz}$ frequency in the early stages of the disease, but at fast frequencies such as $6-12 \mathrm{~Hz}$ in later periods. In the late stages of the disease, EEG deteriorates completely, and epileptiform discharges are almost continuous. ${ }^{[4]}$

Myoclonic epilepsy, rapidly progressive dementia, and visual hallucinations are clinical clues for the diagnosis. Detection of Lafora bodies by skin biopsy is a commonly used diagnostic method, but the presence of intracellular similar bodies in some childhood storage diseases leads to false-positive results. Genetic analysis is an increasingly preferred method since it is not an invasive procedure such as skin biopsy and does not give false results such as false positivity or false negativity. ${ }^{[5]}$ The EMP2A gene localized at $6 q 24$ 
encodes the Laforin protein, a phosphatase, and accounts for $60 \%$ of LD cases. The NHLRC1 gene localized on chromosome $6 q 22.3$ encodes the Malin protein and is detected in $20-30 \%$ of LD cases. Laforin acts as a phosphatase in complex carbohydrates required for normal glycogen homeostasis. With the Laforin gene mutation, glycogen is highly phosphorylated, and branching is reduced. This leads to decreased resolution. Furthermore; Laforin also forms a complex with Malin and plays role in correction of certain substrates marked with ubiquitin by Malin. These substrates are involved in the regulation of glycogen biosynthesis. As a result of glycogen synthesis dysregulation due to lack of Malin and Laforin, Lafora body formation occurs. ${ }^{[6]}$ Lafora bodies can be found in many tissues such as the brain, skin, liver, heart, and spinal cord. Extra-neurological symptoms are not usually seen in patients. It can be detected in the ductal cells of eccrine sweat glands and myoepithelial cells of apocrine sweat glands. ${ }^{[5]}$

In the initial stages of the disease, cryptogenic occipital lobe epilepsy and Gastaut idiopathic childhood epilepsy should be considered in the differential diagnosis. In addition, LD can mimic juvenile myoclonic epilepsy and Univerricht-Lundborg disease.

There is no definitive treatment of LD, but the treatment is based on support and symptomatic treatment, in general. VPA, benzodiazepines, levetiracetam, piracetam, and zonisamide may be used together for myoclonus that significantly disrupts daily activities of patients. Carbamazepine, phenytoin, gabapentin, and pregabalin should be avoided to prevent worsening of myoclonus. It has been predicted that gene therapy may be an option or a permanent solution in recent years. ${ }^{[7]}$

Approximately $40 \%$ of patients with epilepsy have monogenic, chromosomal, and multifactorial genetic diseases in the etiology. Nowadays, it is important to define these genes in diseases with poor prognosis such as progressive myoclonic epilepsy, especially LD, since it can give information on neurotransmitter and identifying ion channels. ${ }^{[8]}$

Conclusion- As a result; myoclonic epilepsies and LD should be included in our preliminary diagnoses in adolescent cases accompanied by rapid cognitive deterioration and basic rhythm deceleration in EEG.

Acknowledgment- We would like to thank the techni- cal team of Bursa Uludag University Medical Faculty who helped prepare the cases.

Informed Consent- Written informed consent was obtained from patients who participated in this study.

Peer-review- Externally peer-reviewed.

Authorship Contributions- Concept: A.B.D., I.H.B.; Design: A.B.D.; Supervision: A.B.D., I.H.B.; Data collection \&/or processing: A.B.D.; Analysis and/or interpretation: A.B.D., I.H.B.; Literature search: A.B.D.; Writing: A.B.D., I.H.B.; Critical review: A.B.D., I.H.B.

Conflict of interest-The authors declare that they have no conflict of interest.

Financial Disclosure: The authors declared that this study has received no financial support.

\section{References}

1. Turnbull J, Tiberia E, Striano P, Genton $P$, Carpenter S, Ackerley CA, et al. Lafora disease. Epileptic Disord 2016;18(S2):38-62. [CrossRef]

2. Singh S, Satishchandra P, Shankar SK, Ganesh S. Lafora disease in the indian population: EPM2A and NHLRC1 gene mutations and their impact on subcellular localization of laforin and malin. Hum Mutat 2008;29(6):E1-12. [CrossRef]

3. Sinha S, Satishchandra P, Gayathri N, Yasha TC, Shankar SK. Progressive myoclonic epilepsy: A clinical, electrophysiological and pathological study from South India. J Neurol Sci 2007;252(1):16-23. [CrossRef]

4. Panzica F, Canafoglia L, Franceschetti S, Binelli S, Ciano C, Visani $\mathrm{E}$, et al. Movement-activated myoclonus in genetically defined progressive myoclonic epilepsies: EEG-EMG relationship estimated using autoregressive models. Clin Neurophysiol 2003;114(6):1041-52. [CrossRef]

5. Andrade DM, Ackerley CA, Minett TS, Teive HA, Bohlega S, Scherer SW, et al. Skin biopsy in Lafora disease: Genotype-phenotype correlations and diagnostic pitfalls. Neurology 2003;61(11):1611-4. [CrossRef]

6. Ianzano L, Zhang J, Chan EM, Zhao XC, Lohi H, Scherer SW, et al. Lafora progressive myoclonus epilepsy mutation database-EPM2A and NHLRC1 (EPM2B) genes. Hum Mutat 2005;26(4):397.

7. Ferlazzo E, Trenite DK, de Haan GJ, Nitschke FF, Ahonen S, Gasparini $S$, et al. Update on pharmacological treatment of progressive myoclonus epilepsies. Curr Pharm Des 2017;23(37):566266. [CrossRef]

8. Lohi $\mathrm{H}$, Turnbull J, Zhao XC, Pullenayegum S, lanzano L, Yahyaoui $M$, et al. Genetic diagnosis in Lafora disease: Genotype-phenotype correlations and diagnostic pitfalls. Neurology 2007;68(13):996-1001. [CrossRef] 